\title{
Empirical Study on the Graduate Destination from Local Agricultural Colleges and Universities-Taking the X School of Heilongjiang Bayi Agricultural University as an Example QU Yanpeng ${ }^{1}$, YANG Yanqiu ${ }^{1}$, Li Ying ${ }^{1}$, ZHANG Aizhong $^{1}$, TONG Dandan ${ }^{1}$, SHAN Xufei $^{1}$, LIAN Shuai ${ }^{1 *}$
}

College of Animal Science and Veterinary Medicine, Heilongjiang Bayi Agricultural University, Daqing, 163319, P. R China

DOI: $10.36347 /$ sjebm.2020.v07i04.001

| Received: 23.03.2020 | Accepted: 31.03.2020 | Published: 08.04.2020

*Corresponding author: LIAN Shuai

Abstract

Original Research Article

Based on the employment data of graduates from X School of Heilongjiang Bayi Agricultural University from 2017 to 2019, the author analyzed and studied the four employment trends of the undergraduate graduates, postgraduate study, employment by signing formal agreements, flexble employment, and underemployment, in combination with annual comparison, gender comparison and regional comparison.Suggestions are put forward from such aspects as defining the orientation of running schools, optimizing the objectives of talent training, school-enterprise cooperation in running schools, innovating the mode of collaborative education, strengthening employment guidance, establishing correct employment motivation, strengthening macro-control and ensuring the supply of systems, etc., so as to promote the high-quality employment of graduates from local agricultural colleges and universities.

Keywords: employment destination, undergraduate graduates, local agricultural colleges and universities.

Copyright @ 2020: This is an open-access article distributed under the terms of the Creative Commons Attribution license which permits unrestricted use, distribution, and reproduction in any medium for non-commercial use (NonCommercial, or CC-BY-NC) provided the original author and source are credited.

\section{INTRODUCTION}

Employment is the biggest livelihood, it's an important factor related to social harmony, the note of playing the people's happy life, especially the employment of college graduates is the foundation of social livelihood, and it plays an important role in the process of social stability and development. At present, the employment situation of college graduates is very grim, and employment is the most important indicator of the country's political and economic prosperity. As one of the largest employment groups, the employment of college graduates has a direct impact on the regional economic development. The employment status of college graduates is not only closely related to the vital interests of individuals and families, but also closely related to the overall situation of deepening the reform and thriving development of the whole society and even the whole country.

Heilongjiang Bayi Agricultural University, located in the northernmost part of China, it is a provincial full-time agricultural university, which has cultivated a large number of talents of compound application and technical skills for the development of agricultural and animal husbandry industry in China. This text takes the employment trend data of graduates of X School of Heilongjiang Bayi Agricultural University from 2017 to 2019 as the research object, analyzes the employment trend of graduates of local agricultural universities from multiple perspectives, analyzes the reasons, and studies the countermeasures, so as to provide some reference opinions for changing the employment situation of graduates of local agricultural universities in the new period of China.

\section{OBJECTS AND METHODS OF THE SURVEY}

In this study, the original employment data of graduates from $X$ School of Heilongjiang Bayi Agricultural University is adopted, and the graduates from this college from 2017 to 2019 are taken as the research object to conduct data analysis and research on the employment trend of graduates. This study divides the graduates' employment trend into four types: postgraduate study, employment by signing formal agreements (it is divided into two categories: suited to the professional training and unsuited to the professional

training), flexble employment, and underemployment.T he basic employment situation of graduates from 2017 to 2019 is as follows: 
Table-1: Basic employment situation of graduates from 2017 to 2019

from X School of Heilongjiang Bayi Agricultural University

\begin{tabular}{|c|c|c|c|c|c|c|c|}
\hline $\begin{array}{c}\text { Year of } \\
\text { graduation }\end{array}$ & $\begin{array}{c}\text { Number of } \\
\text { graduation }\end{array}$ & Male & Proportion & Female & Proportion & $\begin{array}{c}\text { Number of } \\
\text { employed people }\end{array}$ & $\begin{array}{c}\text { Initial } \\
\text { employment rate }\end{array}$ \\
\hline 2017 & 316 & 154 & $48.73 \%$ & 162 & $51.27 \%$ & 285 & $90.19 \%$ \\
\hline 2018 & 370 & 204 & $55.14 \%$ & 166 & $44.86 \%$ & 353 & $95.41 \%$ \\
\hline 2019 & 383 & 180 & $47.00 \%$ & 203 & $53.00 \%$ & 356 & $92.95 \%$ \\
\hline $2017 \sim 2019$ & 1069 & 538 & $50.33 \%$ & 531 & $49.67 \%$ & 994 & $92.98 \%$ \\
\hline
\end{tabular}

As can be seen from Table 1, the number of undergraduate graduates increased year by year from 2017 to 2019, and the total number of three-year graduates was 1,069 . The proportion of male students was decreasing, while that of female students was increasing year by year. The proportion of male students and female students in the total number of graduates in the three years was basically the same. The number of employed people was 994, and the employment rate remains at a high level, with an average employment rate of $92.98 \%$. The employment rate has been on the rise for three years.

\section{RESULTS AND ANALYSIS \\ Overall situation}

Table 2 is the data table of the employment of 1069 undergraduates from 2017 to 2019. Among them, among all the graduates, 36.86 percent chose to continue their studies, 56.13 percent chose employment, of which 48.18 percent were students with formal contracts and 7.95 percent were students with flexible employment. Among the students who signed up formally, 39.57 percent of the graduates got the job suited to their professional training and 8.861 percent of the graduates got the job does not match their specialty, $7.02 \%$ of graduates were underemployed.

Table-2: Description of employment destination of undergraduate graduates from 2017 2019

\begin{tabular}{|c|c|c|}
\hline \multicolumn{2}{|c|}{ Employment destination } & Proportion (\%) \\
\hline \multicolumn{2}{|c|}{ Postgraduate study } & 36.86 \\
\hline \multirow{2}{*}{ Employment by agreement } & Suited to the professional training & 39.57 \\
\hline & Unsuited to the professional training & 8.61 \\
\hline \multicolumn{2}{|c|}{ Flexible employment } & 7.95 \\
\hline \multicolumn{2}{|c|}{ Underemployment } & 7.02 \\
\hline
\end{tabular}

\section{Annual contrast}

With the continuous development of China's economy, the talent training quality of local agricultural universities is constantly improving, and the employment destination of graduates is also quietly changing. Table 3 is the annual contrast of the employment destination of graduates from 2017 to 2019.

Table-3: Annual contrast of employment destination of undergraduate's from2017 to 2019

\begin{tabular}{|c|c|c|c|c|c|c|}
\hline \multirow{2}{*}{$\begin{array}{c}\text { Year of } \\
\text { graduation }\end{array}$} & \multicolumn{5}{|c|}{$\begin{array}{c}\text { Eostgraduate } \\
\text { study }\end{array}$} & \multicolumn{3}{|c|}{ Employment by agreemet } & \multicolumn{2}{c|}{$\begin{array}{c}\text { Flexible } \\
\text { employment }\end{array}$} & Underemployment \\
\cline { 3 - 6 } & Total & Suited & Unsuited & 3.16 & 9.81 \\
\hline 2017 & 44.62 & 42.41 & 35.44 & 6.96 & 7.30 & 4.59 \\
\hline 2018 & 34.86 & 53.24 & 44.86 & 8.38 & 12.53 & 7.05 \\
\hline 2019 & 32.38 & 48.04 & 37.86 & 10.18 & & \\
\hline
\end{tabular}

According to the Job Segregation Theory proposed by the Segmented Labor Market Theory, after the expansion of the scale of higher education, due to the multiple segmentation of the labor market, college graduates would mainly work in the main labor market, rather than in the secondary labor market. Therefore, the expansion of the scale of higher education will lead to the reduction of the relative opportunities for graduates to find jobs in the main labor market [1] and increase the pressure of employment; it will also lead to the increasing number of graduates who choose to study for master's degree year by year. According to the official figures from China's ministry of education, the number of applicants nationwide for graduate programs rose from 2.01 million in 2017 to 2.9 million in 2019 . From 2017 to 2019, the number of undergraduate students who apply for master's degrees from X college of Heilongjiang Bayi Agricultural University has also been increasing year by year, but it can be seen from Table 3 that the proportion of undergraduate graduates 
going to graduate school in employment destination was decreasing year by year, from $44.62 \%$ in 2017 to $32.38 \%$ in 2019 , with a large decline. This was also in line with the current postgraduate entrance examination environment in China. And in China, the number of postgraduate candidates increased every year, and the number of enrollment did not increase significantly, that leaded to an increase in the annual exam admission ratio, followed by a decline in the success rate of postgraduate entrance examination. The number of employment in agreement showed an increasing trend, which accounted for the highest proportion of students' employment. The proportion of employment suited to the professional training fluctuated, and the proportion of employment unsuited to the professional training increased year by year, from $6.96 \%$ in 2017 to $10.18 \%$ in 2019. The number of employment suited to the professional training is closely related to the economic development of China's animal husbandry industry. The number of flexible employment had been increasing year by year, and it was increasing rapidly. From 2017 to 2019 , it was $3.16 \%, 7.30 \%$ and $12.53 \%$ respectively. More and more graduates chose the form of flexible employment, which is closely related to the current economic diversity of China. The number of underemployed people showed an overall downward trend, and from 2017 to 2019, it was $9.81 \%, 4.59 \%$ and $7.05 \%$ respectively. The number of graduate students declined the main employment destination of this part of graduates turned to flexible employment and employment unsuited to the professional training in agreement.

\section{Gender Contrast}

Due to the influence of graduates' own quality and social environment, there are gender differences in $t$ he employment of local agricultural college graduates. Table 4 is the gender contrast of employment destinatio ns for undergraduates from 2017 to 2019.

Table-4: Gender contrast of employment destinations for undergraduates from 2017 to 2019.

\begin{tabular}{|c|c|c|c|c|c|c|c|c|c|c|}
\hline \multirow{4}{*}{$\begin{array}{c}\text { Year of } \\
\text { graduation }\end{array}$} & \multicolumn{10}{|c|}{ Gender contrast of employment destinations for undergraduates（Units:\%） } \\
\hline & \multirow{2}{*}{\multicolumn{2}{|c|}{$\begin{array}{l}\text { Postgraduate } \\
\text { study }\end{array}$}} & \multicolumn{4}{|c|}{ Employment in agreemet } & \multirow{2}{*}{\multicolumn{2}{|c|}{$\begin{array}{c}\text { Flexible } \\
\text { employment }\end{array}$}} & \multirow{2}{*}{\multicolumn{2}{|c|}{ Underemployment }} \\
\hline & & & & & Un & ted & & & & \\
\hline & Male & $\begin{array}{c}\text { Femal } \\
\mathrm{e}\end{array}$ & Male & $\begin{array}{c}\text { Femal } \\
\mathrm{e}\end{array}$ & Male & $\begin{array}{c}\text { Femal } \\
\mathrm{e}\end{array}$ & Male & $\begin{array}{c}\text { Fema } \\
\text { le }\end{array}$ & Male & Female \\
\hline 2017 & 18.99 & 25.63 & 21.20 & 14.24 & 2.22 & 4.75 & 1.27 & 1.90 & 5.06 & 4.75 \\
\hline 2018 & 15.95 & 18.92 & 29.46 & 15.41 & 2.97 & 5.41 & 4.59 & 2.70 & 2.16 & 2.43 \\
\hline 2019 & 11.23 & 21.15 & 19.58 & 18.28 & 4.18 & 6.01 & 8.09 & 4.44 & 3.92 & 3.13 \\
\hline
\end{tabular}

It can be seen from Table 4 that the proportion of male students choosing contract employment and flexible employment was higher than that of female students, and the proportion of female students going to graduate school and signing up for majors was significantly higher than that of male students. The proportion of male students going to graduate school was decreasing year by year, while the proportion of female students going to graduate school was generally decreasing. This may be because the main employment enterprises for local application-oriented college graduates are agricultural and animal husbandry enterprises. The working environment is relatively tough, and female students have higher requirements on the working environment, so they hope to choose graduate school to avoid direct employment after graduation, or choose a job with a good working environment with a transdisciplinary majors. The proportion of male students and female students employed by the agreement of their majors was decreasing and increasing year by year. The proportion of male and female students who do not get employment through agreements and flexible employment was increasing year by year. The proportion of underemployed males and females was on the decline.

\section{Region Contrast}

Heilongjiang Bayi Agricultural University is located in Heilongjiang, the northernmost province of China. Students of X School come from more than 20 provinces and cities in China, and most of them are from Heilongjiang province. The school is committed to cultivating talents with composite application and technical skills. The graduates are distributed in many regions of China, showing certain characteristics. Table 5 shows the comparison of the employment destinations of undergraduates with employment by agreement and flexible employment in each province from 2017 to 2019. In the research data, males accounted for $56.17 \%$ and females $43.83 \%$. Pic. 1 shows the retional distribution of employment destinations of undergraduates with employment by agreement and flexible employment from 2017 to 2019. 
Table-5: Contrast of the employment destinations of undergraduates with employment by agreement and flexible employment in each province from 2017 to 2019 (\%)

\begin{tabular}{|c|c|c|c|c|c|c|c|c|c|c|c|c|c|c|c|c|c|c|c|c|c|c|c|c|c|c|}
\hline $\begin{array}{ll} \\
0\end{array}$ & 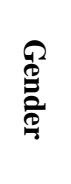 & 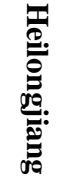 & 兽: & 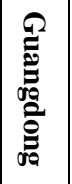 & 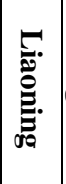 & 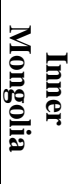 & : & $\begin{array}{l}\frac{\pi}{9} \\
\stackrel{9}{\mathscr{y}}\end{array}$ & 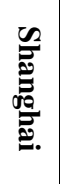 & 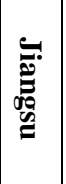 & 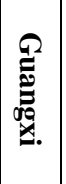 & 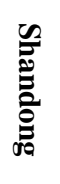 & 胥: & 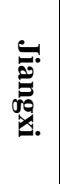 & 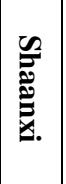 & 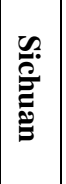 & 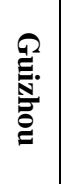 & $\begin{array}{l}\text { D } \\
\text { E. }\end{array}$ & : & 苞 & $\begin{array}{l}\text { : } \\
\text { : }\end{array}$ & 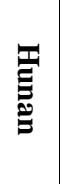 & $\underset{\Xi}{\mathbb{\Xi}}$ & 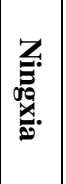 & 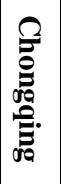 & $\Xi$ \\
\hline \multirow{3}{*}{$\stackrel{N}{\Xi}$} & 男 & 14.58 & 2.78 & 14.58 & \begin{tabular}{|l|l|}
5.56 \\
\end{tabular} & 4.17 & 1.39 & 1.39 & \begin{tabular}{|l|}
1.39 \\
\end{tabular} & 4.17 & \begin{tabular}{|l|}
0.69 \\
\end{tabular} & \begin{tabular}{ll|}
1.39 \\
\end{tabular} & 0 & 0 & 0. & 0 & 0 & 0.69 & 0 & 0.69 & 0 & 0 & 0.69 & 0 & 0 & 0 \\
\hline & 女 & 18.06 & 6.94 & 7.64 & \begin{tabular}{|l|}
4.17 \\
\end{tabular} & 0 & 0.69 & $\begin{array}{ll}0.69 \\
\end{array}$ & 0.69 & \begin{tabular}{|l|}
1.39 \\
\end{tabular} & \begin{tabular}{|l|}
0 \\
\end{tabular} & 0.69 & 0.69 & 0 & 0 & \begin{tabular}{|l|}
0.69 \\
\end{tabular} & \begin{tabular}{|l|}
0.69 \\
\end{tabular} & 0.69 & 0 & 0.69 & 0 & 0 & & \begin{tabular}{|l|}
0.69 \\
\end{tabular} & \begin{tabular}{|l|}
0.69 \\
\end{tabular} & 0 \\
\hline & 总数 & 32.64 & 9.72 & 22.22 & \begin{tabular}{|l|}
9.72 \\
\end{tabular} & 4.17 & 2.08 & 2.08 & 2.08 & \begin{tabular}{|l|l|}
5.56 \\
\end{tabular} & \begin{tabular}{|l|}
0.69 \\
\end{tabular} & 2.08 & \begin{tabular}{|l|}
0.69 \\
\end{tabular} & 0 & \begin{tabular}{|l|}
0 \\
\end{tabular} & \begin{tabular}{|l|}
0.69 \\
\end{tabular} & 0.69 & 1.39 & 0 & 1.39 & 0 & 0 & 0.69 & \begin{tabular}{|l|}
0.69 \\
\end{tabular} & 0.69 & 0 \\
\hline \multirow{3}{*}{$\stackrel{\mathfrak{N}}{\stackrel{\infty}{\infty}}$} & 男 & 20.98 & 10.71 & \begin{tabular}{|l|}
8.04 \\
\end{tabular} & 2.23 & 4.02 & 4.46 & \begin{tabular}{|l|}
1.79 \\
\end{tabular} & 0.45 & 0.45 & 3.57 & 0.89 & \begin{tabular}{|l|}
1.34 \\
\end{tabular} & 0.45 & 0.45 & \begin{tabular}{|l|}
0.45 \\
\end{tabular} & 0.45 & \begin{tabular}{|l|}
0 \\
\end{tabular} & 0.45 & \begin{tabular}{|l|}
0 \\
\end{tabular} & 0 & 0 & 0 & \begin{tabular}{|l|}
0 \\
\end{tabular} & \begin{tabular}{|l|}
0 \\
\end{tabular} & 0 \\
\hline & 女 & 10.27 & 8.93 & 3.13 & 3.57 & 3.13 & 3.57 & 1.79 & 0.89 & \begin{tabular}{|l|}
0 \\
\end{tabular} & \begin{tabular}{|l|}
0.89 \\
\end{tabular} & 0 & \begin{tabular}{|l|}
0 \\
\end{tabular} & 0 & \begin{tabular}{|l|}
0.89 \\
\end{tabular} & \begin{tabular}{|l|}
0.89 \\
\end{tabular} & 0.45 & 0 & 0 & 0 & 0.45 & 0 & 0 & 0 & 0 & 0 \\
\hline & 总数 & 31.25 & 19.64 & 11.16 & 5.80 & 7.14 & 8.04 & 3.57 & 1.34 & \begin{tabular}{|l|} 
\\
\end{tabular} & \begin{tabular}{|l|}
4.46 \\
\end{tabular} & 0.89 & 1.34 & 0.45 & \begin{tabular}{|l|}
1.34 \\
\end{tabular} & 1.34 & 0.89 & 0 & 0.45 & 0 & 0.45 & 0 & 0 & 0 & 0 & 0 \\
\hline \multirow{3}{*}{$\stackrel{\widetilde{0}}{\tilde{b}}$} & 男 & 23.28 & 8.62 & 5.17 & 3.88 & 1.29 & 0.86 & 1.29 & 2.59 & \begin{tabular}{|l|}
0.86 \\
\end{tabular} & \begin{tabular}{|l|}
0.43 \\
\end{tabular} & 0.43 & \begin{tabular}{|l|}
0.86 \\
\end{tabular} & 1.29 & \begin{tabular}{|l|}
0 \\
\end{tabular} & \begin{tabular}{|l|}
0 \\
\end{tabular} & 0.43 & 0 & 0.43 & 0 & 0 & 0.86 & 0 & 0 & 0 & 0 \\
\hline & 女 & 22.41 & 11.21 & 3.45 & 1.72 & 0 & 0 & \begin{tabular}{|l|}
0.86 \\
\end{tabular} & 1.72 & \begin{tabular}{|l|}
1.29 \\
\end{tabular} & \begin{tabular}{|l|}
0.43 \\
\end{tabular} & 2.16 & \begin{tabular}{|l|}
0.86 \\
\end{tabular} & 0 & \begin{tabular}{|l|}
0.43 \\
\end{tabular} & 0 & 0 & 0 & 0 & 0 & 0.43 & 0 & 0 & 0 & 0 & 0.43 \\
\hline & 总数 & 45.69 & 19.83 & 8.62 & \begin{tabular}{|l|}
5.60 \\
\end{tabular} & 1.29 & 0.86 & \begin{tabular}{|l|}
2.16 \\
\end{tabular} & 4.31 & \begin{tabular}{|l|}
2.16 \\
\end{tabular} & 0.86 & 2.59 & \begin{tabular}{|l|}
1.72 \\
\end{tabular} & 1.29 & \begin{tabular}{|l|}
0.43 \\
\end{tabular} & 0 & 0.43 & 0 & \begin{tabular}{|l|}
0.43 \\
\end{tabular} & 0 & 0.43 & 0.86 & 0 & 0 & 0 & 0.43 \\
\hline \multirow{3}{*}{ 蓑旁 } & 男 & 20.33 & \begin{tabular}{|l|}
8.00 \\
\end{tabular} & 8.50 & 3.67 & 3.00 & 2.33 & 1.50 & 1.50 & \begin{tabular}{|l|}
1.50 \\
\end{tabular} & 1.67 & 0.83 & \begin{tabular}{|l|}
0.83 \\
\end{tabular} & 0.67 & \begin{tabular}{|l|}
0.17 \\
\end{tabular} & \begin{tabular}{|l|}
0.17 \\
\end{tabular} & 0.33 & \begin{tabular}{|l|}
0.17 \\
\end{tabular} & \begin{tabular}{|l|}
0.33 \\
\end{tabular} & \begin{tabular}{|l|}
0.17 \\
\end{tabular} & 0 & 0.33 & \begin{tabular}{|l|l|} 
\\
\end{tabular} & 0 & 0 & 0 \\
\hline & 女 & 16.83 & 9.33 & 4.33 & 3.00 & \begin{tabular}{|l|l|}
1.17 \\
\end{tabular} & 1.50 & 1.17 & 1.17 & \begin{tabular}{|l|}
0.83 \\
\end{tabular} & \begin{tabular}{|l|}
0.50 \\
\end{tabular} & 1.00 & 0.50 & 0 & \begin{tabular}{|l|}
0.50 \\
\end{tabular} & \begin{tabular}{|l|}
0.50 \\
\end{tabular} & \begin{tabular}{|l|}
0.33 \\
\end{tabular} & 0.17 & \begin{tabular}{|l|}
0 \\
\end{tabular} & 0.17 & 0.33 & 0 & 0 & 0.17 & 0.17 & 0.17 \\
\hline & 总数 & 37.17 & 17.33 & 12.83 & 6.67 & 4.17 & 3.83 & 2.67 & 2.67 & 2.33 & 2.17 & 1.83 & 1.33 & 0.67 & $0.67 \mid$ & $0.67 \mid$ & 0.67 & 0.33 & 0.33 & 0.33 & 0.33 & 0.33 & 0.17 & $0.17 \mid$ & 0.17 & 0.17 \\
\hline
\end{tabular}

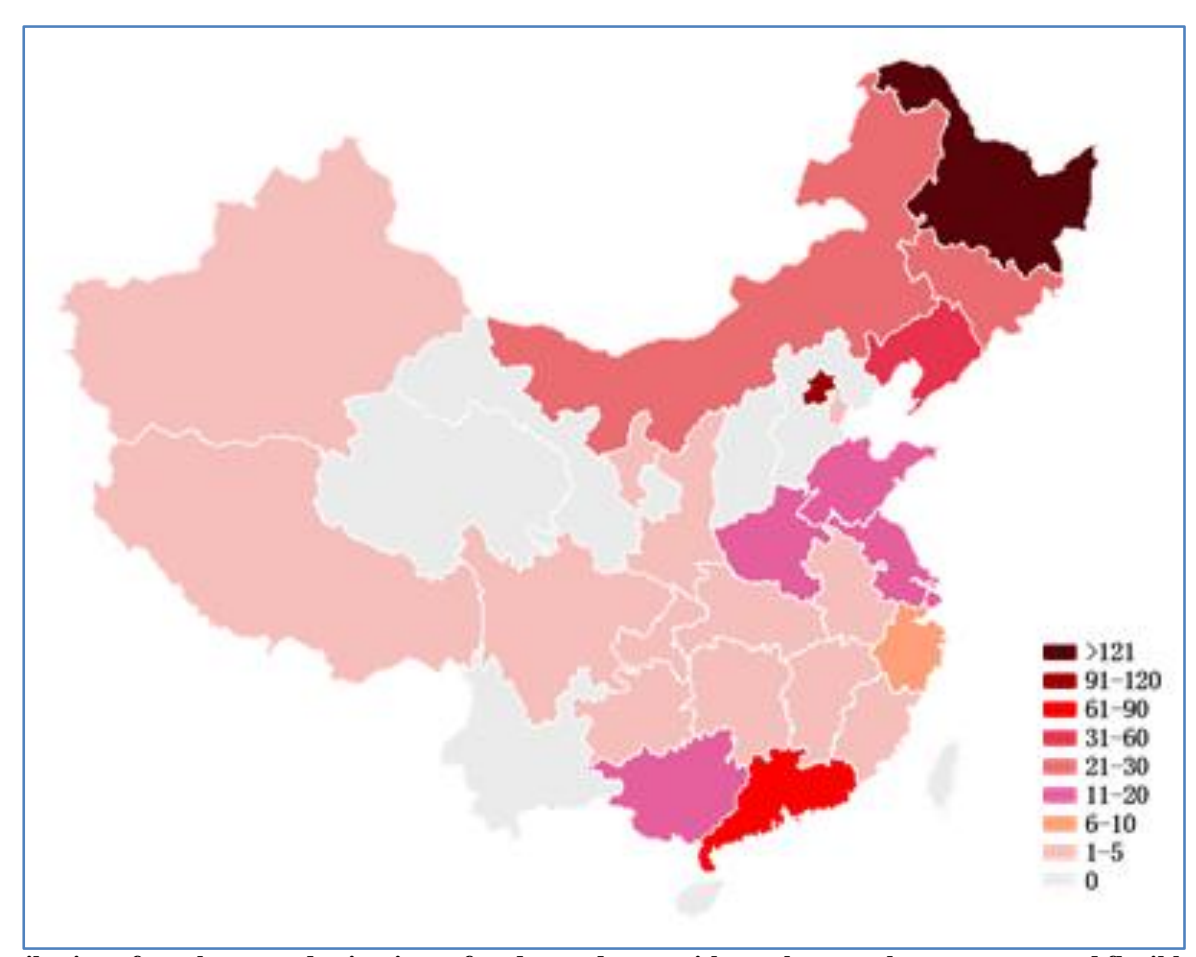

Pic-1: Retional distribution of employment destinations of undergraduates with employment by agreement and flexible employment from 2017 to 2019

As can be seen from table 5, the employment of undergraduate graduates from 2017 to 2019 was distributed in 25 provinces, and the top ten provinces were Heilongjiang, Beijing, Guangdong, Liaoning, Inner Mongolia, Jilin, Henan, Shanghai, Jiangsu and Guangxi. The proportion of choosing employment in Heilongjiang province showed an increasing trend, with the total number of three-year graduates accounting for $36.12 \%$, and the proportion of undergraduate graduates from 2017 to 2019 accounts for $32.64 \%, 31.25 \%$ and $45.69 \%$ respectively. Among them, the proportion of male students in employment increased year by year, which an obvious advantage has compared with other provinces. The proportion of graduates who choose to work in Beijing, Shanghai and Zhejiang was increasing year by year. Among them, the proportion of female students who choose to work in Beijing and Shanghai was increasing year by year. The proportion of graduates who choose Guangdong and Liaoning for employment was decreasing year by year. The proportion of male students who choose Guangdong and Liaoning for employment was decreasing year by year, and the proportion of female students was also decreasing. The proportion of graduates who choose to work in Inner Mongolia and Jilin showed a decreasing trend. The trend of the other provinces didn't change obviously. From 2017 to 2019, the number of provinces in which the employment of undergraduates is 
distributed showed an increasing trend, indicating that the employment of graduates was more dispersed.

Combined with Figure 1 and Table 5, we can know that there was a higher percentage of graduates choosing the same province to work as the university located in, especially the male students. To analyze the possible reasons, one is the enrollment of Heilongjiang province is larger. Secondly, it's related to employment preferential policy in Heilongjiang province. Thirdly, it is related to the ideological guidance in the process of employment guidance that encourages graduates to stay in the same province as the university located in. The forth reason is that the male students' requirement on the employment environment is not high. The proportion of graduates returning to their hometowns is relatively high. Shandong and Henan are the provinces with a large proportion of students, and the proportion of graduates who choose employment is also large. The coastal provinces with political centers and developed economy and the neighboring provinces where the universities are located account for a large proportion of the employment, and the employment of female students is more inclined to the economically developed provinces and coastal provinces.

\section{DISCUSSION AND SUGGESTIONS}

Make clear the orientation of running a school, optimize the goal of talent training, and improve the social adaptability of students majoring in agriculture

When formulating the training objectives of agriculture-related specialties, local agricultural colleges and universities should go deep into the other relevant employing units of rural areas and agriculturerelated enterprises to fully analyze the relevant positions and occupational abilities of agriculturerelated specialties, In order to meet the needs of some students in the postgraduate entrance examination, it is necessary to carry out classification training, so as to make the butt joint of professional development and the extension of the agricultural industry chain, the education content and the professional standards, and the teaching process and the production process, so as to improve the adaptability of agricultural talents training to the society, and improve the degree of conformity of talent training objectives. Special emphasis is given that priority to culture techniques applied, focusing on applied ability training, based on the trend of the development of the agricultural industrialization, agriculture, industry, and trade integration, at the same time of strengthening wide basis, permeate multi-disciplinary knowledge content, closely combining with the characteristics of agricultural professional, research and select the ways and methods of serving rural areas that are suitable for the provinces and schools. By radiating scientific research achievements, scientific and technological advantages and intellectual advantages to rural areas in a certain way, students can be better trained to solve some applied technical problems in production practice, so that they can have the ability of production, operation and management, so as to better serve the local agricultural and animal husbandry economic construction.

School-enterprise cooperation in running schools,
innovation in collaborative education mode,
improves the employability of graduates of local
agricultural colleges and universities. In today's society, school-enterprise cooperation in education has become a trend. For local agricultural colleges and universities, they should comply with the requirements of social development and send interdisciplinary innovative talents with solid professional foundation and strong practical ability to the national society through the talent cultivation method of "integration of agriculture, science and technology, and education". Institutionalists believe that some purposeful behavior can improve the initial signal and affect the entire organizational network [2]. Through in-depth cooperation in running schools, the concept, information, knowledge and skills of enterprises are solidified into the training program, and the gap between the training objectives of colleges and universities and the standards of enterprise employment can be shortened, which is conducive to promoting employment. At present, the common method is the order-type talent cultivation mechanism of enterprises, that is, the named alliance class of enterprises. As a complementary mechanism of natural classes, enterprises provide internship and practice sites, and participate in the formulation of school talent cultivation programs. The courses are divided into theoretical training and extracurricular practice, including enterprise introduction and cultural concept, brand quality, workplace mentality, career planning, visiting and learning, internship, etc.. In addition, expanding the opportunities for summer interns to the lower grades can also be realized. At the same time, universities and enterprises can carry out effective cooperation in the field of scientific research and technology promotion, and realize the integration of production, learning and research, so that students can quickly adapt to the needs of enterprise development, shorten the probation period, and improve their employability.

\section{Strengthen employment guidance, establish correct employment motives, and promote high-quality employment for graduates.}

According to Herzberg's Two-Factor Need Motivation Theory [3], there are two kinds of factors that stimulate people's motivation, one is maintenance factors, including salary level, working environment, social welfare and occupational safety,etc.,the other is incentive factors, such as achievement, recognition, responsibility, development and other factors. At present, with the severe employment situation, college students' employment psychological pressure increases, 
the number of people are not optimistic about the employment prospects continue to increase, many college students regard continuing to study for graduate degree as the way to solve the employment. However, studying for a graduate degree is not the only way to obtain high-quality employment, and improving the core competitiveness of college students is the fundamental to achieve high-quality employment. In addition, with the expansion of the scale of graduate students, the "Crowding out Effect" of graduate students on the employment of undergraduates will gradually emerge, and the pressure of competitive advantage positions of undergraduates will further increase. Therefore, it is important for us educators to focus on enhancing employment guidance, how to change college students' career outlook, set up correct employment motivation, and then promote graduates' high-quality employment.

\section{Strengthen macro-control, ensure institutional supply, and further guide the rational flow of graduates}

Mobility is the characteristic trend and internal requirement of social labor employment under the market economy system. To realize the full flow of graduates, especially the conscious flow to the western region and the difficult industries, we need the joint efforts of the government, the society, the school and the family. The Push-Pull Theory has a strong explanatory power on the factors influencing the employment location of college students. In the 1880s, E. Ravenstein put forward the rudiment of Push-Pull Theory -- the migration rule [4]. One is the force to promote labor migration, including the push from economically underdeveloped areas (such as low income, increased production cost, poor production environment, etc.) and the pull from economically developed areas (such as high income, more employment opportunities, good living and working environment, etc.); The other is the forces that hinder population migration, including the pull from economically underdeveloped regions (such as family reunion, acquaintance society, etc.) and the push from economically developed regions (such as fierce competition, unfamiliar environment, etc.)[5].College graduates are important talents for the construction and development of economically underdeveloped areas. How to promote the employment of graduates in economically underdeveloped areas requires the government to plan for the future, carry out careful investigation and research, actively adjust and improve various policies, and promote the balance of regional economic development from the perspective of macro policies. At the same time, the employment subsidy and compensation policies for college students will be further improved to make these areas more attractive to college graduates.

\section{ACKNOWLEDGMENTS}

This work was supported by the teaching reserch subject of Heilongjiang Bayi Agricultural University(NDJY1905); The reserch subject of Party building of Heilongjiang Bayi Agricultural University (XDJ19102) and Heilongjiang province education science 13th five-year plan youth special project (GJD1319017).

\section{REFERENCES}

1. Cain GG. The challenge of segmented labor market theories to orthodox theory: A survey. Journal of Economic Literature. 1976 Dec 1;14(4):1215-57.

2. Tina Dacin M, Goodstein J, Richard Scott W. Institutional theory and institutional change: Introduction to the special research forum. Academy of management journal. 2002 Feb 1;45(1):45-56.

3. Herzberg: Frederick. Herzberg on Motivation [J].Penton Education Division. 1991,(12).

4. Ravenstein EG. The birthplaces of the people and the laws of migration. Trübner; 1876.

5. BOGUE D J. Streams of Migration Between Subregions:A Pilot Study of Migration F lows between Environments[J]. Population. 1958, 13(2):328- 345 . 